\title{
THE EFFECT OF HEPATITIS C VIRUS INFECTION ON INSULIN RESISTANCE IN CHRONIC HEMODIALYSIS PATIENTS
}

\author{
Walid Ahmed RagabAbd El Hamid, Essam El Din Mahmoud Lotfy, Yousef Ahmed Kadry, Lamia \\ Abdulwahab Mohammed
}

Internal Medicine Department, Faculty of Medicine, Zagazig University, Egypt

\begin{abstract}
Background: Hepatitis $\mathrm{C}$ virus infection has strong relationship with insulin resistance in general population. Insulin resistance increases risk of cardiovascular events in chronic kidney disease patients.This work is intended to study the interrelation between Hepatitis $\mathrm{C}$ virus infection and insulin resistance among end stage renal disease patients on regular hemodialysis.

Methods: It included a total number of 90 subjects. They were divided into two groups: Group 1 (45 subjects Hepatitis C viruspositivepatientson regular hemodialysis), Group 2 (45 subjects Hepatitis C virusnegative patients on regular hemodialysis). All patients included in this study were subjected to the following: Full clinical assessment,Complete blood picture, alanine aminotransferase, aspartate aminotransferase, creatinine, blood urea, fasting plasma glucose, Coagulation profile, serum calcium, serum phosphorus, serum parathyroid hormone, Hepatitis $\mathrm{C}$ virusantibodies, human immunodeficiency virus antibodies, hepatitis surface antigen, fasting serum insulin and fasting serum C-peptide.

Results: Our study reported that no statically significant difference in Homeostatic model assessment of insulin resistance between the two studied groups. Homeostatic model assessment of insulin resistance has significant correlation to age, weight, body mass index,serum parathyroid hormone, serum creatinine, urea reduction ratio and serum ferritin.

Conclusion: We couldn't detect any strong correlation between Hepatitis C virus seropositivity and insulin resistance in hemodialysis patients, but we detected strong relationship of insulin resistance to age, weight, body mass index, serum parathyroid hormone, serum creatinine, urea reduction ratio and serum ferritin in hemodialysis patients.
\end{abstract}

Keywords: Insulin resistance, Hepatitis C virus, Chronic kidney disease, Hemodialysis

\section{INTRODUCTION}

$\mathrm{CV}$ infection causes several extra-
hepatic manifestations. manifestations are hypothesized to be due to activation of immune system and direct effect of virus itself ${ }^{[1]}$.Type 2 DM is considered to be the most important extrahepatic manifestation of infection by $\mathrm{HCV}$ virus ${ }^{[2]}$.

Patients on regular dialysis are exposed to high risk for $\mathrm{HCV}$ infection. That is attributed to prolonged use of AV fistula and possible contact with contaminated instruments. The incidence of $\mathrm{HCV}$ infection in hemodialysis population differs widely among countries from only less than $5 \%$ in some countries up to approximately $60 \%$ in other countries ${ }^{[3]}$.

The relationship between $\mathrm{HCV}$ and type 2 DM has been suggested by the high frequency of type $2 \mathrm{DM}$ among $\mathrm{HCV}$ patients and high prevalence of $\mathrm{HCV}$ infection among type 2 diabetic patients ${ }^{[4]}$. Type 2 DM develops as a result of resistance to insulin and decreased beta cells production of insulin. In $\mathrm{HCV}$ core-gene transgenic mice the injection of insulin decreases blood sugar level but less potent effect than in control group and also basal 
insulin was higher in HCV infected mice indicting insulin resistance in $\mathrm{HCV}$ infected mice $^{[5]}$

Diabetic nephropathy is the commonest etiology of end-stage renal disease (ESRD) worldwide. The number of patients suffering from DM and associated CKD is increasing and is said to be epidemic in distribution with poor prognosis ${ }^{[6]}$.

So CKD is commonly associated with abnormal metabolism of carbohydrate, resistance to insulin and infection by $\mathrm{HCV}$ [7]. The presence of insulin resistance predicts development of cardiovascular diseases which is the leading cause of death from CKD. Also progression of microalbuminurea and gross proteinuria in patients with renal impairment is strongly associated with insulin resistance ${ }^{[8]}$.

The aim of our work was intended to study the interrelation between Hepatitis $\mathrm{C}$ virus infection and insulin resistance among end stage renal disease patients on regular hemodialysis.

\section{SUBJECTS AND METHODS}

This study was carried out in Internal Medicine Department, Zagazig University Hospitals, Faculty of Medicine, ZagazigUniversity.

\section{A) Subjects}

The study included 90 cases with end stage renal disease on regular hemodialysis three times per week. These patients were selected from hemodialysis unit of the internal medicine department, Faculty of Medicine, Zagazig University. They were classified into two main groups according to presence or absence of HCV antibodies.

1) Group 1 included 45 patients who were HCV positive and negative for HBsAg and anti-HIV Ab. They were 29 males and 16 females with age ranging from 21-73 years old with mean $46.22 \pm 13.38$ years old.

2) Group2 included 45 patients who were $\mathrm{HCV}$ negative and negative for $\mathrm{HBsAg}$ and anti-HIV Ab.They were 25 males and 20 females with age ranging from 17-75 years old with mean $44.20 \pm 14.71$ years old.

\section{B) Methods of Study}

All subjects of the study were subjected to the following:

Thorough history and full clinical examination:

Special emphasis on duration of CKD, etiology of CKD (If known), duration of dialysis, drugs taken by the patients and presence of jaundice or ascites.Also pasthistory of DM, hypertension or smoking.

Laboratory investigations:

- Complete blood picture.

- Serum ALTand AST.

- Serum creatinine and blood urea.

- Fasting plasma glucose.

- PT, PTT and INR.

- Serum calcium and serum phosphorus.

- Serum iPTH.

- HCV Antibodies, HIV Antibodies, HBsAg.

- Fasting serum insulin and fasting serum C-peptide.

Kits (Human insulin and C-peptide) were provided by Chemux Bioscience, South San Francisco, USA. Fasting insulin was done to calculate HOMA-IR to identify presence of insulin resistance and fasting C-peptide was done to evaluate its correlation to insulin resistance in CKD especially in $\mathrm{HCV}$ infected patients.

- HOMA-IR which equals ([fasting insulin $(\mathrm{mU} / \mathrm{L}) \quad \mathrm{x}$ fasting glucose (mmol/L)]/22.5). Results of HOMA-IR equal or more than 2.5 were considered positive for insulin resistance. 


\section{RESULTS}

Table 1: Demographic data of group 1and group 2

\begin{tabular}{lcccc}
\hline \multicolumn{1}{c}{ Variable } & Group 1 & Group 2 & Test & P \\
Age (years) & & & & \\
Mean \pm SD & $46.22 \pm 13.38$ & $44.20 \pm 14.71$ & $0.682 *$ & 0.497 \\
Median (Range) & $51(21-73)$ & $46(17-75)$ & $(\mathrm{NS})$ \\
Age $\leq \mathbf{4 8 . 5}$ years & $46.7 \%$ & $53.3 \%$ & $0.400 \S$ & 0.527 \\
Age $>\mathbf{4 8 . 5}$ years & $53.5 \%$ & $46.7 \%$ & & $(\mathrm{NS})$ \\
Sex & & & $0.741 \S$ & 0.389 \\
Male & $64.4 \%$ & $55.6 \%$ & $44.4 \%$ & $(\mathrm{NS})$ \\
\hline Female & $35.6 \%$ & & \\
\hline
\end{tabular}

(*): Independent Student t-test, (\$): Chi-square test and (SD): Standard deviation.

Table (1) shows no statistical significant differences between group 1 and group 2 regarding age and sex distribution.

Table 2: Clinical data of group 1 and group 2

\begin{tabular}{|c|c|c|c|c|}
\hline Clinical data & Group 1 & Group 2 & Test & $\mathbf{P}$ \\
\hline \multicolumn{5}{|l|}{ Weight (kg) } \\
\hline $\begin{array}{l}\text { Mean } \pm S D \\
\text { Range }\end{array}$ & $\begin{array}{c}63.60 \pm 14.47 \\
35-95\end{array}$ & $\begin{array}{c}73.12 \pm 19.07 \\
31-110\end{array}$ & $-2.57 \bullet$ & $\begin{array}{c}0.010 \\
(\mathrm{~S})\end{array}$ \\
\hline \multicolumn{5}{|l|}{$\underline{\text { Height (m) }}$} \\
\hline $\begin{array}{l}\text { Mean } \pm \text { SD } \\
\text { Range }\end{array}$ & $\begin{array}{l}1.66 \pm 0.06 \\
1.48-1.74\end{array}$ & $\begin{array}{l}1.68 \pm 0.04 \\
1.55-1.75\end{array}$ & $-1.86 \bullet$ & $\begin{array}{c}0.062 \\
\text { (NS) }\end{array}$ \\
\hline \multicolumn{5}{|l|}{$\underline{\text { BMI }\left(\mathrm{kg} / \mathrm{m}^{2}\right)}$} \\
\hline $\begin{array}{l}\text { Mean } \pm \text { SD } \\
\text { Range }\end{array}$ & $\begin{array}{l}22.82 \pm 4.55 \\
14.57-32.87\end{array}$ & $\begin{array}{l}25.50 \pm 6.18 \\
12.26-37.62\end{array}$ & $-2.56 \bullet$ & $\begin{array}{l}0.010 \\
(\mathrm{~S})\end{array}$ \\
\hline \multicolumn{5}{|l|}{$\underline{\text { SBP }(\mathrm{mmHg})}$} \\
\hline $\begin{array}{l}\text { Mean } \pm \text { SD } \\
\text { Range }\end{array}$ & $\begin{array}{c}126.44 \pm 16.53 \\
90-160\end{array}$ & $\begin{array}{c}129.55 \pm 20.33 \\
90-180\end{array}$ & $-0.64 \bullet$ & $\begin{array}{l}0.520 \\
\text { (NS) }\end{array}$ \\
\hline \multicolumn{5}{|l|}{$\underline{\mathrm{DBP}}(\mathbf{m m H g})$} \\
\hline $\begin{array}{l}\text { Mean } \pm \text { SD } \\
\text { Range }\end{array}$ & $\begin{array}{c}80.22 \pm 10.33 \\
60-100\end{array}$ & $\begin{array}{c}81.77 \pm 12.48 \\
60-110\end{array}$ & $-0.56 \bullet$ & $\begin{array}{r}0.577 \\
\text { (NS) }\end{array}$ \\
\hline \multicolumn{5}{|l|}{ Dialysis (years) } \\
\hline $\begin{array}{l}\text { Mean } \pm \text { SD } \\
\text { Range }\end{array}$ & $\begin{array}{c}7.93 \pm 5.25 \\
1-17\end{array}$ & $\begin{array}{c}5.64 \pm 4.40 \\
1-22\end{array}$ & $-2.18 \bullet$ & $\begin{array}{l}0.029 \\
(\mathrm{~S})\end{array}$ \\
\hline
\end{tabular}

(•): Mann Whitney U test, (§):Chi-square test, (SD): Standard deviation, (SBP): Systolic blood pressure and (DBP): Diastolic blood pressure.

Table (2) shows no statistical significant differences between the two groups regarding height, systolic blood pressure and diastolic blood pressure. Weight was higher significantly in group 2 with mean value $73.12 \mathrm{~kg}$ and dialysis duration was longer significantly in group 1 with mean value 7.93 years. 
Table 3: Laboratory data of group 1 and group 2

\begin{tabular}{|c|c|c|c|c|}
\hline Variable & Group 1 & Group 2 & Test & $\mathbf{P}$ \\
\hline \multicolumn{5}{|l|}{ WBC's (x103/mm3) } \\
\hline$\overline{\text { Mean } \pm \text { SD }}$ & $5.67 \pm 1.83$ & $6.71 \pm 2.04$ & \multirow{2}{*}{$-2.511 \bullet$} & \multirow{2}{*}{$\begin{array}{c}0.012 \\
(\mathrm{~S})\end{array}$} \\
\hline Median (Range) & $5.4(3-10.3)$ & $6(3.30-11.40)$ & & \\
\hline \multicolumn{5}{|l|}{ Hemoglobin $(\mathrm{g} / \mathrm{dl})$} \\
\hline Mean \pm SD & $10.82 \pm 1.60$ & $10.07 \pm 1.66$ & \multirow[t]{2}{*}{$-1.970 \bullet$} & \multirow{2}{*}{$\begin{array}{c}0.049 \\
(\mathrm{~S})\end{array}$} \\
\hline Median (Range) & $10.9(7.6-14.5)$ & $10(7-14.2)$ & & \\
\hline \multicolumn{5}{|l|}{ Platelet (x103/mm3) } \\
\hline Mean \pm SD & $187.51 \pm 56.22$ & $241.20 \pm 83.83$ & \multirow[t]{2}{*}{-3.370} & \multirow{2}{*}{$\begin{array}{c}0.001 \\
(\mathrm{HS})\end{array}$} \\
\hline Median (Range) & $177(96-371)$ & $249(115-508)$ & & \\
\hline \multicolumn{5}{|l|}{ Creatinine (mg/dl) } \\
\hline$\overline{\text { Mean } \pm \text { SD }}$ & $10.66 \pm 2.83$ & $11.55 \pm 2.17$ & \multirow[t]{2}{*}{$-1.529 \bullet$} & \multirow{2}{*}{$\begin{array}{c}0.126 \\
\text { (NS) }\end{array}$} \\
\hline Median (Range) & $10.59(5.35-18.84)$ & $11.19(7.16-15.69)$ & & \\
\hline \multicolumn{5}{|l|}{ URR\% } \\
\hline$\overline{\text { Mean } \pm \text { SD }}$ & $69.73 \pm 8.10$ & $67.34 \pm 7.94$ & \multirow[t]{2}{*}{$-1.622 \bullet$} & \multirow{2}{*}{$\begin{array}{c}0.105 \\
\text { (NS) }\end{array}$} \\
\hline Median (Range) & $69.90(55-95.60)$ & $66.70(55-92)$ & & \\
\hline URR $\% \leq 68.5$ & $42.2 \%$ & $57.8 \%$ & $2.178 \S$ & 0.140 \\
\hline URR \% $>68.5$ & $57.8 \%$ & $42.2 \%$ & & $(\mathrm{NS})$ \\
\hline \multicolumn{5}{|l|}{ Calcium (mg/dl) } \\
\hline$\overline{\text { Mean } \pm \text { SD }}$ & $9.00 \pm 0.82$ & $9.11 \pm 0.88$ & \multirow[t]{2}{*}{$-0.484 \bullet$} & \multirow{2}{*}{$\begin{array}{c}0.628 \\
\text { (NS) }\end{array}$} \\
\hline Median (Range) & $9.08(6.60-10.62)$ & $8.83(7.10-10.91)$ & & \\
\hline \multicolumn{5}{|c|}{ Phosphorus (mg/dl)Mean \pm} \\
\hline$\overline{\mathrm{SD}}$ & $4.41 \pm 1.52$ & $4.95 \pm 1.63$ & \multirow[t]{2}{*}{$-1.578 \bullet$} & \multirow{3}{*}{$\begin{array}{c}0.115 \\
(\mathrm{NS})\end{array}$} \\
\hline Median (Range) & $4.27(2.21-7.45)$ & $4.83(2.29-9.69)$ & & \\
\hline \multicolumn{4}{|l|}{ iPTH (pg/ml) } & \\
\hline Mean \pm SD & $646.22 \pm 486.87$ & $396.03 \pm 358.39$ & \multirow[t]{2}{*}{$2.679 •$} & \multirow{3}{*}{$\begin{array}{c}0.007 \\
(\mathrm{~S})\end{array}$} \\
\hline Median (Range) & $556(12.40-1900)$ & $190(17.89-1100)$ & & \\
\hline \multicolumn{4}{|l|}{ Ferritin (ng/ml) } & \\
\hline$\overline{\text { Mean } \pm \text { SD }}$ & $1289.78 \pm 1291.67$ & $905.16 \pm 1035.49$ & \multirow[t]{2}{*}{$-1.933 \bullet$} & \multirow{2}{*}{$\begin{array}{c}0.043 \\
(\mathrm{~S})\end{array}$} \\
\hline Median (Range) & $880(155-6596)$ & $485(43.4-9465)$ & & \\
\hline \multicolumn{5}{|c|}{ Transferrin saturation } \\
\hline$\overline{\text { Mean } \pm \text { SD }}$ & $38.96 \pm 23.40$ & $32.88 \pm 16.23$ & \multirow[t]{2}{*}{$-0.924 \bullet$} & \multirow{2}{*}{$\begin{array}{c}0.035 \\
(\mathrm{~S})\end{array}$} \\
\hline Median (Range) & $30.7(11.9-98.39)$ & $26.14(12.01-68.95)$ & & \\
\hline
\end{tabular}

(•): Mann Whitney U test, $(\$)$ :Chi-square test, (SD): Standard deviation, (WBC’s): White blood cells, (URR): Urea reduction ratio and (iPTH): Intact parathyroid hormone.

Table (3) shows no significant differences between group 1 and group 2 regarding serum creatinine, URR, serum calcium and serum phosphorous. WBC's count is significantly higher in group 2 with median $6 * 10^{3}$ cells $/ \mathrm{mm}^{3}$. Hemoglobin is significantly higher in group 1 with median
$10.9 \mathrm{gm} / \mathrm{dl}$. iPTH is significantly higher in group 1 with median $556 \mathrm{pg} / \mathrm{ml}$. Platelets count is significantly higher in group 2 with median $249 \times 10^{3} / \mathrm{mm}^{3}$. Serum ferritin and transferrin saturation are significantly higher in group 1 with median values $880 \mathrm{ng} / \mathrm{ml}$ and $30.7 \%$ respectively. 
Table 4: Special investigation of group 1 and group 2

\begin{tabular}{|c|c|c|c|c|}
\hline Variable & Group 1 & Group 2 & Test & $\mathbf{P}$ \\
\hline $\begin{array}{l}\frac{\text { Insulin }(\mu \mathrm{IU} / \mathrm{ml})}{\text { Mean } \pm \text { SD }} \\
\text { Median (Range) }\end{array}$ & $\begin{array}{c}11.21 \pm 10.45 \\
7.02(1.55-40.77)\end{array}$ & $\begin{array}{c}10.21 \pm 10.16 \\
5.80(1.32-52.72)\end{array}$ & $-0.101 \bullet$ & $\begin{array}{l}0.920 \\
\text { (NS) }\end{array}$ \\
\hline $\begin{array}{l}\text { C-peptide(ng/ml) } \\
\text { Mean } \pm \text { SD } \\
\text { Median (Range) }\end{array}$ & $\begin{array}{c}8.67 \pm 3.32 \\
9.37(3.42-12.70)\end{array}$ & $\begin{array}{c}8.50 \pm 2.77 \\
8.91(3.52-12.70)\end{array}$ & $-0.408 \bullet$ & $\begin{array}{l}0.683 \\
\text { (NS) }\end{array}$ \\
\hline $\begin{array}{l}\text { Fasting Glucose }(\mathrm{mg} / \mathrm{dl}) \\
\text { Mean } \pm \text { SD } \\
\text { Median (Range) }\end{array}$ & $\begin{array}{c}82.11 \pm 50.66 \\
72(48.80-387.9)\end{array}$ & $\begin{array}{c}83.84 \pm 27.71 \\
77.80(53.50-185.3)\end{array}$ & $-1.618 \bullet$ & $\begin{array}{l}0.106 \\
\text { (NS) }\end{array}$ \\
\hline $\begin{array}{l}\text { HOMA-IR } \\
\text { Mean } \pm \text { SD } \\
\text { Median } \\
\text { Range } \\
\text { Insulin resistance Negative }\end{array}$ & $\begin{array}{c}2.115 \pm 2.059 \\
1.181 \\
0.207-8.137\end{array}$ & $\begin{array}{c}2.241 \pm 2.671 \\
1.241 \\
0.189-15.489\end{array}$ & $-0.085 \bullet$ & $\begin{array}{l}0.932 \\
\text { (NS) }\end{array}$ \\
\hline Positive & $\begin{array}{l}75.6 \% \\
24.4 \%\end{array}$ & $\begin{array}{l}71.1 \% \\
28.9 \%\end{array}$ & $0.227 \S$ & $\begin{array}{l}0.634 \\
\text { (NS) }\end{array}$ \\
\hline
\end{tabular}

(•): Mann Whitney U test, (§):Chi-square test, (SD): Standard deviation and (HOMA-IR): Homeostatic model assessment of insulin resistance.

Table (4) shows no significant differences insulin, fasting $\mathrm{C}$ peptide, fasting glucose, between group 1 and group 2 in fasting HOMA-IR and insulin resistance..

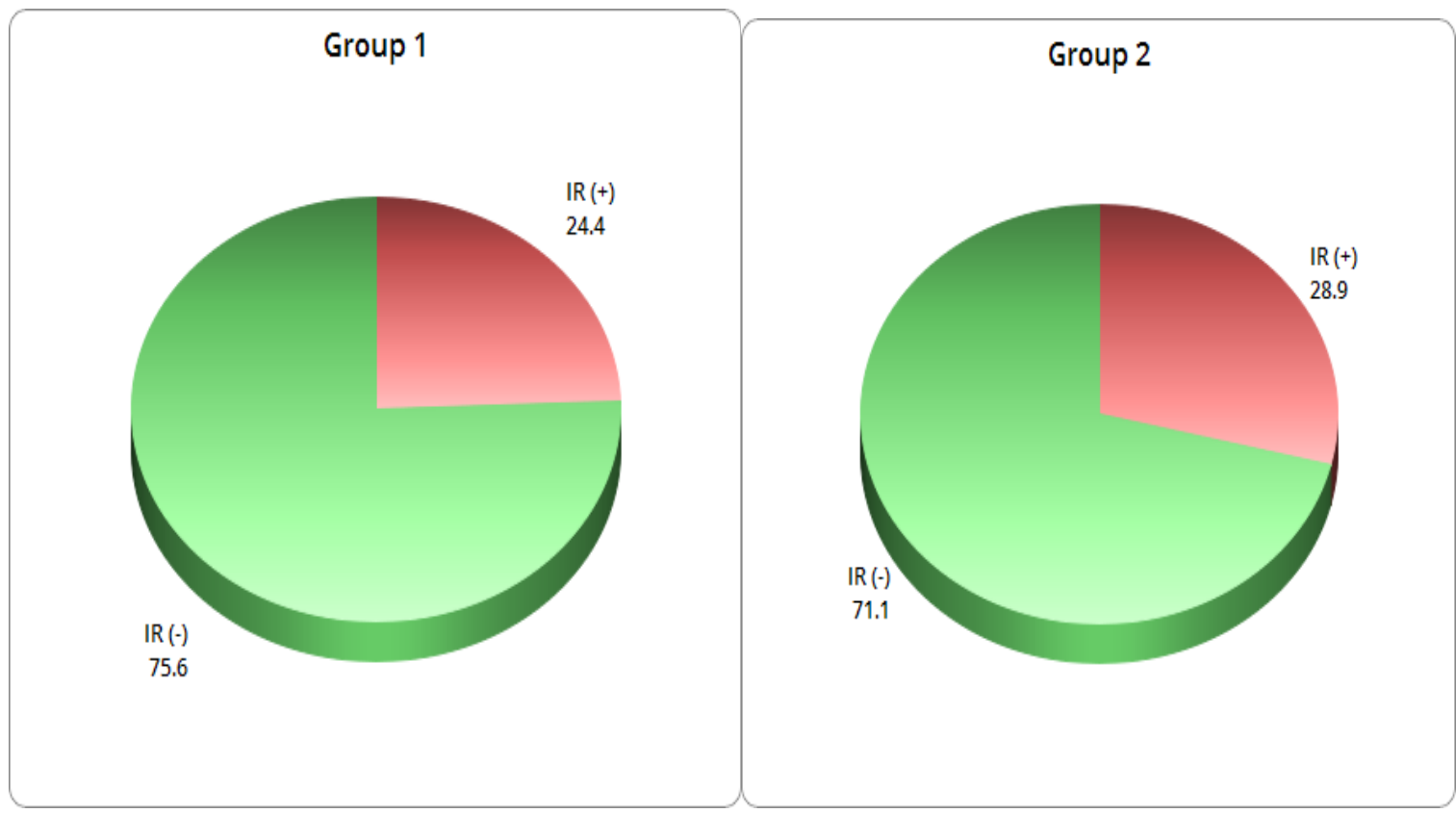

Fig. 1: Distribution of insulin resistance $\{I R\}$ among group 1 and group 2 . 
Table 5: HOMA-IR among URR\% subgroupsin group 1 and group 2.

\begin{tabular}{lcccc}
\hline HOMA-IR & Group 1 & Group 2 & Test & p-value \\
URR\% $\leq \mathbf{6 8 . 5}$ & $(\mathrm{n}=19)$ & $(\mathrm{n}=26)$ & $-0.506 \bullet$ & 0.613 \\
Mean \pm SD & $2.469 \pm 1.664$ & $2.280 \pm 1.882$ & & $(\mathrm{NS})$ \\
Median & 1.925 & 1.698 & & \\
Range & $0.399-5.872$ & $0.220-8.259$ & & \\
& & & & \\
URR\% >68.5\% & $(\mathrm{n}=26)$ & $(\mathrm{n}=19)$ & $-0.069 \bullet$ & 0.945 \\
Mean \pm SD & $1.857 \pm 2.303$ & $2.188 \pm 3.537$ & & $(\mathrm{NS})$ \\
Median & 0.923 & 0.738 & & \\
Range & $0.207-8.137$ & $0.189-15.489$ & & \\
& & & & \\
Test & $-2.253 \bullet$ & $-1.885 \bullet$ & & \\
p-value (Sig.) & $0.024(\mathrm{~S})$ & $0.059(\mathrm{NS})$ & & \\
\hline
\end{tabular}

(•) Mann Whitney U test, (URR): Urea reduction ratio, (SD): Standard deviationand (HOMA-IR): Homeostatic model assessment of insulin resistance.

Table (5) shows no significant differences of HOMA-IR between low URR subgroups in either group 1 or group 2 and also between high URR subgroups in either group 1 or group 2. HOMA-IR is significantly higher with low URR subgroup of group 1 versus high URR subgroup in group 1.

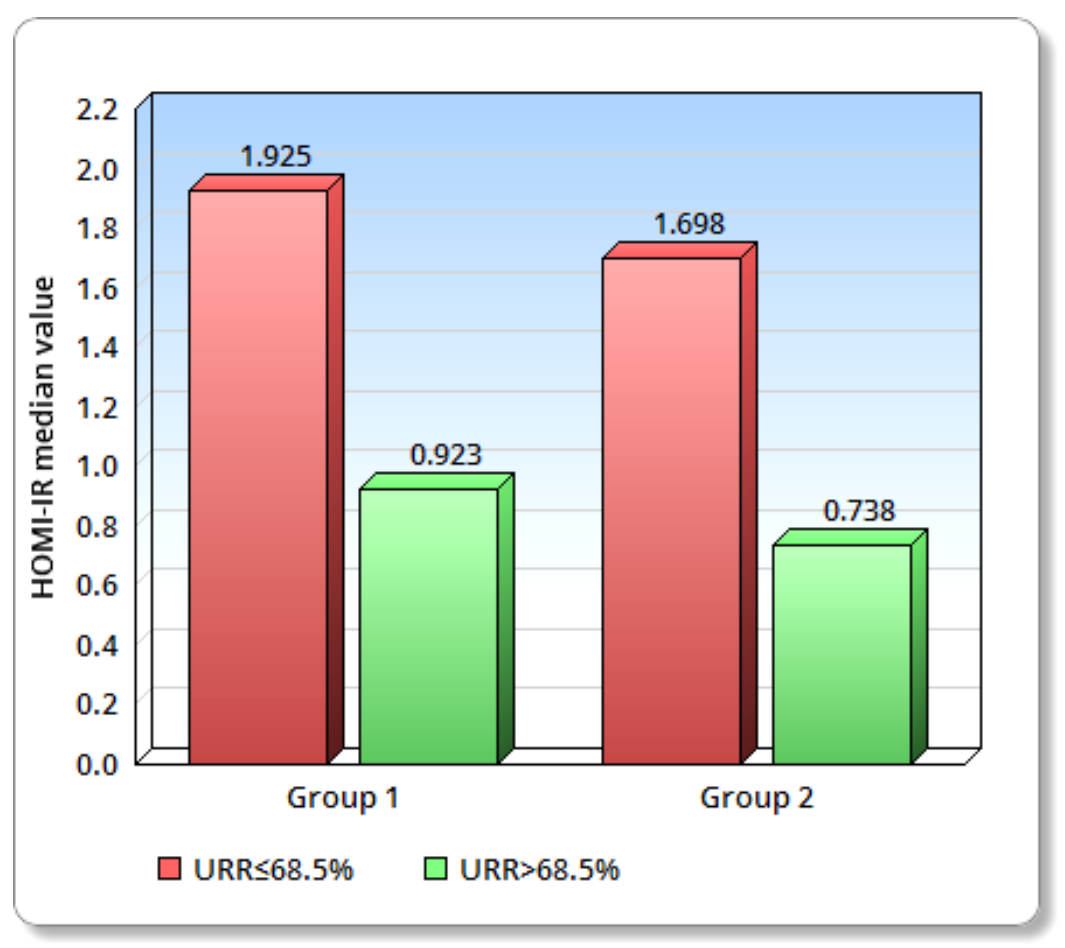

Fig. 2: HOMA-IR median value among URR subgroups of group 1 and group 2 
Table 6: Correlation betweenHOMA-IR and selected study parameters

\begin{tabular}{|c|c|c|c|c|}
\hline \multirow[t]{2}{*}{ Variables } & \multicolumn{2}{|c|}{ Group 1} & \multicolumn{2}{|c|}{ Group 2} \\
\hline & $\mathrm{r}$ & $\mathrm{p}$-value & $\mathrm{r}$ & $\mathrm{p}$-value \\
\hline Age (years) & +0.205 & $0.176(\mathrm{NS})$ & +0.347 & $0.019(\mathrm{~S})$ \\
\hline Weight (kg) & +0.284 & $0.059(\mathrm{NS})$ & +0.411 & 0.005 (HS) \\
\hline Height $(\mathrm{m})$ & +0.019 & $0.903(\mathrm{NS})$ & +0.084 & 0.583 (NS) \\
\hline BMI $\left(\mathrm{kg} / \mathrm{m}^{2}\right)$ & +0.278 & $0.064(\mathrm{NS})$ & +0.439 & 0.003 (HS) \\
\hline $\begin{array}{l}\text { Systolicblood pressure } \\
(\mathrm{mmHg})\end{array}$ & +0.096 & $0.532(\mathrm{NS})$ & -0.017 & $0.913(\mathrm{NS})$ \\
\hline $\begin{array}{l}\text { Diastolicblood pressure } \\
(\mathrm{mmHg})\end{array}$ & +0.006 & $0.970(\mathrm{NS})$ & +0.151 & $0.323(\mathrm{NS})$ \\
\hline Hemodialysis duration (years) & +0.061 & $0.691(\mathrm{NS})$ & -0.115 & $0.450(\mathrm{NS})$ \\
\hline WBC's $\left(\times 10^{3} / \mathrm{mm}^{3}\right)$ & -0.063 & $0.679(\mathrm{NS})$ & +0.173 & $0.255(\mathrm{NS})$ \\
\hline Hemoglobin $(\mathrm{g} / \mathrm{dl})$ & +0.010 & $0.950(\mathrm{NS})$ & +0.080 & 0.601 (NS) \\
\hline Platelet count $\left(\times 10^{3} / \mathrm{mm}^{3}\right)$ & -0.077 & $0.616(\mathrm{NS})$ & +0.035 & $0.822(\mathrm{NS})$ \\
\hline Creatinine $(\mathrm{mg} / \mathrm{dl})$ & +0.270 & $0.073(\mathrm{NS})$ & -0.230 & $0.129(\mathrm{NS})$ \\
\hline URR\% & -0.378 & $0.010(\mathrm{~S})$ & -0.269 & $0.074(\mathrm{NS})$ \\
\hline Calcium (mg/dl) & -0.319 & $0.033(\mathrm{~S})$ & +0.112 & $0.465(\mathrm{NS})$ \\
\hline Phosphorus (mg/dl) & +0.471 & $0.001(\mathrm{HS})$ & +0.188 & $0.216(\mathrm{NS})$ \\
\hline iPTH (pg/ml) & +0.375 & $0.011(\mathrm{~S})$ & -0.257 & $0.089(\mathrm{NS})$ \\
\hline Ferritin (ng/ml) & -0.227 & $0.133(\mathrm{NS})$ & -0.132 & $0.387(\mathrm{NS})$ \\
\hline Transferrin saturation (\%) & -0.313 & $0.036(\mathrm{~S})$ & -0.277 & $0.066(\mathrm{NS})$ \\
\hline Fasting Insulin $(\mu \mathrm{IU} / \mathrm{ml})$ & +0.904 & $<0.001(\mathrm{HS})$ & +0.952 & $<0.001(\mathrm{HS})$ \\
\hline Fasting C peptide (ng/ml) & +0.652 & $<0.001$ (HS) & +0.508 & $<0.001(\mathrm{HS})$ \\
\hline Glucose (mg/dl) & +0.194 & $0.202(\mathrm{NS})$ & +0.558 & $<0.001(\mathrm{HS})$ \\
\hline
\end{tabular}

(r): Spearman's rank correlation coefficient, (BMI): Body mass index, (WBC's): White blood cells, (URR): Urea reduction ratio and (iPTH): Intact parathyroid hormone.

This table shows that HOMA-IR in group 1 is strongly correlated to URR, serum calcium, serum phosphorus, iPTH, transferrin saturation, fasting insulin and fasting $\mathrm{C}$ peptide. HOMA-IR in group2 is strongly correlated to age, weight, BMI, fasting insulin, fasting $\mathrm{C}$ peptide and fasting blood glucose.

Table 7: Univariate logistic regression of potential predictors of insulin resistance in all studied patients $(\mathrm{N}=90)$

\begin{tabular}{lccccl}
\hline Variables & $\beta$ & SE & OR & $95 \%$ CI & p-value \\
HCV (+ve) & -0.228 & 0.478 & 0.796 & $(0.312-2.032)$ & $0.643(\mathrm{NS})$ \\
Age (years) & 0.035 & 0.019 & 1.036 & $(0.999-1.075)$ & $0.049(\mathrm{~S})$ \\
Male & -0.328 & 0.482 & 0.721 & $(0.280-1.853)$ & $0.497(\mathrm{NS})$ \\
Weight $(\mathrm{kg})$ & 0.035 & 0.014 & 1.035 & $(1.007-1.065)$ & $0.016(\mathrm{~S})$ \\
Height $(\mathrm{m})$ & 0.741 & 4.199 & 2.097 & $(0.00-7863.2)$ & $0.860(\mathrm{NS})$ \\
BMI $\left(\mathrm{kg} / \mathrm{m}^{2}\right)$ & 0.123 & 0.045 & 1.131 & $(1.035-1.235)$ & $0.007(\mathrm{HS})$ \\
SBP $(\mathrm{mmHg})$ & 0.003 & 0.013 & 1.003 & $(0.978-1.029)$ & $0.816(\mathrm{NS})$ \\
DBP $(\mathrm{mmHg})$ & 0.011 & 0.021 & 1.011 & $(0.971-1.054)$ & $0.586(\mathrm{NS})$ \\
Hemodialysis duration (years) & 0.023 & 0.047 & 1.023 & $(0.933-1.122)$ & $0.027(\mathrm{NS})$ \\
WBC's $\left(\mathrm{x} 10^{3} / \mathrm{mm}^{3}\right)$ & -0.078 & 0.123 & 0.925 & $(0.726-1.178)$ & $0.528(\mathrm{NS})$ \\
Hemoglobin $(\mathrm{g} / \mathrm{dl})$ & -0.141 & 0.147 & 0.686 & $(0.651-1.158)$ & $0.337(\mathrm{NS})$ \\
Platelet $\left(\mathrm{x} 10^{3} / \mathrm{mm}^{3}\right)$ & -0.004 & 0.004 & 0.996 & $(0.989-1.003)$ & $0.253(\mathrm{NS})$ \\
Creatinine $(\mathrm{mg} / \mathrm{dl})$ & -0.025 & 0.094 & 0.975 & $(0.811-1.172)$ & $0.037(\mathrm{~S})$ \\
URR $(\%)$ & -0.022 & 0.031 & 0.979 & $(0.921-1.040)$ & $0.025(\mathrm{~S})$ \\
Calcium $(\mathrm{mg} / \mathrm{dl})$ & 0.028 & 0.281 & 1.028 & $(0.592-1.784)$ & $0.921(\mathrm{NS})$ \\
Phosphorus $(\mathrm{mg} / \mathrm{dl})$ & 0.247 & 0.150 & 1.281 & $(0.954-1.719)$ & $0.100(\mathrm{NS})$ \\
iPTH (pg/ml) & 0.000 & 0.001 & 1.000 & $(0.999-1.002)$ & $0.042(\mathrm{~S})$ \\
Ferritin & 0.000 & 0.000 & 1.000 & $(1.000-1.001)$ & $0.049(\mathrm{~S})$ \\
Transferrin saturation & -0.002 & 0.012 & 0.998 & $(0.975-1.022)$ & $0.881(\mathrm{NS})$
\end{tabular}


( $\boldsymbol{\beta})$ : regression Coefficient, $(\mathbf{S E})$ : standard error, (OR): Odds Ratio, (95\% CI): $95 \%$ confidence interval, (BMI): Body mass index, (SBP): Systolic blood pressure, (DBP): Diastolic blood pressure, (WBC's): White blood cells, (URR): Urea reduction ratio and (iPTH): Intact parathyroid hormone.

Table (6) shows that there are significant correlation between insulin resistance and each of the variables age, weight, BMI, creatinine, URR, iPTH and ferritin. Also showed no significant correlation between insulin resistance and each of the variables HCV seropositivity, sex, height, blood pressure, hemodialysis duration, WBC's, Hemoglobin, platelet count, serum calcium, serum phosphorus and transferrin saturation.

\section{DISCUSSION}

Infection by Hepatitis $\mathrm{C}$ virus (HCV) is considered to be one of most important health problems in Egypt. Prevalence of $\mathrm{HCV}$ infection in Egypt, especially at ages 15-59 years old, is the highest worldwide. This high prevalence was explained by the wide use of parenteral anti-bilharzial drugs during the period between 1960 to end of $1970^{[9]}$.

$\mathrm{HCV}$ is commonly associated with insulin resistance in general population and occurrence of many complications of $\mathrm{HCV}$ infection is proved to be strongly related to insulin resistance. These complications include fatty liver, liver fibrosis, hepatoma and lack of response to antiviral drugs ${ }^{[10]}$.

CKD is commonly associated with insulin resistance and presence of insulin resistance predicts the development of cardiovascular disease which is the leading cause of death from CKD. Death due to acute cardiovascular events is ten times more in hemodialysis patients than in general population. Also progression of microalbuminuria and gross proteinuria in patients with renal impairment is strongly associated with insulin resistance ${ }^{[8]}$.
Aim of our study is to investigate the correlationof $\mathrm{HCV}$ seropositivity to insulin resistance in chronic hemodialysis patients and to detect the risk factors for insulin resistance in hemodialysis patients.

As regard age and sex distribution in our study there were no significant differences among group 1 and group 2, these results were in agreement with Tsai et al., ${ }^{[11]}$ and Ozdemir et al., ${ }^{[12]}$.

In comparison of clinical data of group 1 and group 2, therewere no statistical significant differences between the two groups regarding height, systolic blood pressure and diastolic blood pressure. Dialysis duration was longer significantly in group 1 with mean duration $7.93 \pm 5.25$ years and these results were in agreement with Tsai et al., ${ }^{[11]}$ and Ozdemir et al., ${ }^{[12]}$. This can be explained by the longer the dialysis duration the higher the chance of nosocomial transmission of $\mathrm{HCV}$ due to sharing items between patients, contamination of dialysis machines, contaminated gloves used by working nurses and lack of proper sterilization of machines after each dialysis session ${ }^{[13]}$.

In our study WBC's and platelets were significantly lower in group 1 than group 2 . These results are in agreement with Tsai et al., ${ }^{[11]}$ and can be due to replication of the $\mathrm{HCV}$ virus in bone marrow, splenic sequestration and immune mediated [14]. Hemoglobin was higher in group 1 and these results are in agreement with Alsaran et al., ${ }^{[15]}$ and can be explained by that hepatic inflammation induces erythropoietin production by liver cells and also due to altered iron metabolism ${ }^{[16]}$.

As regard metabolic profile of group 1 and group 2, there were no significant differences regarding serum creatinine, URR, serum calcium and serum phosphorous. Serum ferritin, iPTH and transferrin saturation were significantly higher in group 1 . These results are in the agreement with Tsai et al., ${ }^{[11]}$ and can be explained by that $\mathrm{HCV}$ induces 
inflammation and increases circulating cytokinesthat stimulate precursors of osteoclasts, and increases RANKL formation by osteoblasts, and so increased bone loss leading to elevated PTH level ${ }^{[17]}$. Also liver inflammation increases release of ferritin in circulation as acute phase reactant and alters iron metabolism ${ }^{[18]}$.

We found special laboratory tests of group 1 and group 2 showed that there were no significant differences between the two groups regarding fasting insulin, fasting $\mathrm{C}$ peptide, fasting glucose, HOMA-IR and insulin resistance. These results are in agreement with Tsai et al., ${ }^{[11]}$ and Adam et al., ${ }^{[19]}$, and against Ozdemir et al., ${ }^{[12]}$ and this can be explained by other factors played role in our study including efficacy of dialysis, relatively small number of patients and BMI was significantly higher in group 2.

As regard HOMA-IR in between low URR subgroups in group 1 versus group 2 and in between high URR subgroups in group 1 versus group 2 there were no significant differences but HOMA-IR was significantly higher with low URR subgroup of group 1 versus high URR subgroup of group 1 . These results are showing the strong relationship between HOMA-IR and URR and these results are in agreement with Chu et al., ${ }^{[20]}$ and can be explained by that with low URR uremic toxins accumulate and affect insulin signaling pathway ${ }^{[20]}$.

Our study showed that HOMA-IR in group 1 is strongly correlated to URR, serum calcium, serum phosphorus, iPTH, transferrin saturation, fasting insulin and fasting $\mathrm{C}$ peptide and these results are in agreement with Tsai et al., ${ }^{[11]}$ and Adam et al., ${ }^{[19]}$ and can be explained by that inflammation induces circulating cytokines that results in hyperparathyroidism ${ }^{[16]}$ and elevated iron indices ${ }^{[18]}$. Low URR is also another important factor that increases prevalence of insulin resistance with $\mathrm{HCV}$ infection due to accumulated uremic toxins ${ }^{[20]}$. Each of elevated fasting blood sugar, fasting insulin and fasting C-peptide can be used as a marker of insulin resistance due to their strong relationship with HOMA-IR.

HOMA-IR in group 2 in our study was strongly correlated to age, weight, BMI, fasting insulin, fasting $\mathrm{C}$ peptide and fasting blood glucose. These results are in agreement with Adam et al., [19] and Gayoso-Diz et al., ${ }^{[21]}$ and can be explained by that insulin resistance increases with age due to decreased physical activity, increased visceral obesity and imbalance of sex hormones in old age ${ }^{[22]}$. Alsoinsulin resistance increases with obesity due to higher free fatty acids and circulating adipokinesinducing systemic resistance to insulin ${ }^{[23] .}$

In our study analysis of the risk of insulin resistance in patients with CKD on regular hemodialysis by univariate binary logistic regression based on demographics, clinical characteristics and laboratory profiles. The results indicate that the probability of insulin resistance was significantly greater with older age [odds ratio (OR): 1.036, 95\% confidence interval (CI): $0.999-1.075, \mathrm{P}=$ 0.049], higher body weight [odds ratio (OR): $1.035,95 \%$ confidence interval (CI): $1.007-1.065, \mathrm{P}=0.016]$, higher $\mathrm{BMI}$ [odds ratio (OR): $1.131,95 \%$ confidence interval $(\mathrm{CI})$ : $1.035-1.235, \mathrm{P}=0.007]$, higher serum Creatinine [odds ratio (OR): $0.975,95 \%$ confidence interval $(\mathrm{CI}): 0.811$ $-1.172, \mathrm{P}=0.037$ ], lower URR [odds ratio (OR): $0.979,95 \%$ confidence interval $(\mathrm{CI})$ : $0.921-1.040, \mathrm{P}=0.025]$, higher $\mathrm{iPTH}$ [odds ratio (OR): $1.000,95 \%$ confidence interval $(\mathrm{CI}): 0.999-1.002, \mathrm{P}=0.042]$ and higher serum Ferritin [odds ratio (OR): $1.000,95 \%$ confidence interval (CI): $1.000-$ $1.001, \mathrm{P}=0.049]$.

\section{CONCLUSION}

In conclusion, we couldn't detect any strong correlation between HCV seropositivity and insulin resistance in hemodialysis patients, but we detected strong relationship of insulin resistance to age, weight, iPTH, serum creatinine, URR and serum ferritin in hemodialysis patients. 
We recommend that more evaluation is needed by more studies on larger groups of hemodialysis patients and to use more sensitive indices of viral load using $\mathrm{HCV}$ RNA PCR, liver fibroscan or liver biopsy in the future studies for more accurate results. Also we recommend reducing risk of insulin resistance among hemodialysis patients by encouraging weight reduction in overweight patients, proper control of secondary hyperparathyroidism, increasing efficiency of dialysis and avoiding unnecessary excess IV iron replacement in hemodialysis patients.

\section{REFERENCES}

1. Cacoub P, Poynard T, Ghillani P, Charlotte F, Olivi M, Peitte JC, et al. Extrahepatic manifestations of chronic hepatitis C MULTIVIRC Group Multidepartment Virus C. Arthritis Rheum; 1999;42:2204-12.

2. Alexander GJ. An association between hepatitis $\mathrm{C}$ virus infection and type 2 diabetes mellitus: What is the connection? Ann Intern Med.; 2000; 133:650-2.

3. Tang $\mathbf{S}$ and Lai KN. Chronic viral hepatitis in hemodialysis patients". HemodialInt; 2005; 9:169- 79.

4. Knobler H, Schihmanter R, Zifroni A, Fenakel G, Schattner A. Increased risk of type 2 diabetes in non cirrhotic patients with chronic hepatitis C virus infection". Mayo ClinProc; 2000; 75:355-9.

5. Shintani Y, Fujie H, Miyoshi H, Tsutsumi T, Tsukamoto K, Kimura S, et al. Hepatitis $\mathrm{C}$ virus infection and diabetes: direct involvement of the virus in the development of insulin resistance. Gastroenterology; 2004; 126:840-8.

6. Jones CA, Krolewski AS, Rogus J, Xue JL, Collins A, Warram JH. Epidemic of end-stage renal disease in people with diabetes in the United States population: do we know the cause? Kidney Int; 2005; 67: 1684-91.

7. Rasic-Milutinovic Z, Perunicic-Pekovic G. Clinical importance and pathogenetic mechanisms of insulin resistance in chronic renal insufficiency (part I): Insulin resistance in patients with chronic renal insufficiency. Med Pregl; 2000; 53:45-50.
8. Liao M, Sung C, Hung K, Wu C, Lo L, Lu K. Insulin Resistance in Patients with Chronic Kidney Disease". Journal of Biomedicine and Biotechnology 2012; 2012: 12.

9. El-Zanaty F, Way A. Egypt Demographic and Health Survey 2008. Ministry of Health (El-Zanaty and Associates and Macro International) 2009; p. 431.

10. El-Zayadi A, Anis M. Hepatitis C virus induced insulin resistance impairs response to anti viral therapy. World J Gastroenterol 2012; January 21; 18(3): 212-24.

11. Tsai H, Chen P, Liu C, Hung P, Chen $M$, Chiang C, et al. Association of hepatitis C virus infection and malnutritioninflammation complex syndrome in maintenance hemodialysis patients. Nephrol Dial Transplant; 2012; 27: 117683.

12. Ozdemir A, Yalinbas B, Selamet U, Eres M, Turkmen F, Kumbasar F, et al. The Effect of Hepatitis C Virus Infection on Insulin Resistance in Chronic Hemodialysis Patients. Yonsei Medical Journal; 2007 48(2): 274-80.

13. Martin P, Fabrizi F. Hepatitis $C$ virus and kidney disease. J Hepatol 2008; 49: 61324.

14. Dietrich DT, Spivak JL. Hematologic Disorders Associated with Hepatitis C Virus Infection and Their Management". Blood Disorders Associated with $\mathrm{HCV}$ • CID; 2003 37: 533-41.

15. Alsaran KA, Sabry AA, Alghareeb AH, Al Sadoon G. Effect of hepatitis $C$ virus on hemoglobin and hematocrit levels in Saudi hemodialysis patients". Ren Fail.; 2009 31(5):349-54.

16. Chen C, Chou C, Tseng Y, Huang C, Chen W, Shih C/ Chronic Hepatitis C Infection Is Associated with Higher Hemoglobin Levels in Hemodialysis Patients, But Hepatitis B Infection Is Not". Dialysis \& Transplantation; 2008: 1-4.

17. Lucaci C, Acalovschi M. Hormonal and Cytokine Implications in the Pathophysiology of Osteoporosis Occurring in Chronic Liver Diseases. Medica- A Journal of Clinical Medicine 2012; 7(4): 358-63.

18. Kamel M. Serum Iron Parameters as Predictors of Insulin Resistance in NonDiabetic HCV +ve Patients on Chronic 
Hemodialysis. Nature and Science; 2013:11(8): 66-71.

19. Adam FU, Torun D, Yigit F, Ozelsancak R, Sezer S, Ozdemir FN et al. Determination of the Impact of Hepatitis C Virus on Insulin Resistance and Arterial Stiffness in Hemodialysis Patients". Renal Failure; 2008; 30:411-5.

20. Chu P, Chiu Y, Lin J, Chen S, Wu K. Effects of Low- and High-Flux Dialyzers on Oxidative Stress and Insulin Resistance". Blood Purif; 2008 26:213-20.

21. Gayoso-Diz P, Gude F, Otero-Gonzalez A, Rodriguez-Alvarez MX, CadarsoSuarez C, García F, et al. Insulin resistance index (HOMA-IR) levels in a general adult population: Curves percentile by gender and age. The EPIRCE stud. Diabetes research and clinical practice; 2011; 9: 146-55.

22. Refaie M, Sayed-Ahmed NA, Bakr A, Abdel Aziz MY, Abdel-Gawad SS, El Kannishi MH. Aging is an Inevitable Risk Factor for Insulin Resistance. Journal of Taibah University Medical Sciences; 2006; $1(1): 30-41$.

23. Shinohara K, Shoji T, Emoto M, Tahara H, Koyama H, Ishimura E, et al. Insulin Resistance as an Independent Predictor of Cardiovascular Mortality in Patients with End-Stage Renal Disease". J Am SocNephrol 2002; 13: 1894-900. 